\title{
脊柱側彎症における背部皮膚温の検討
}

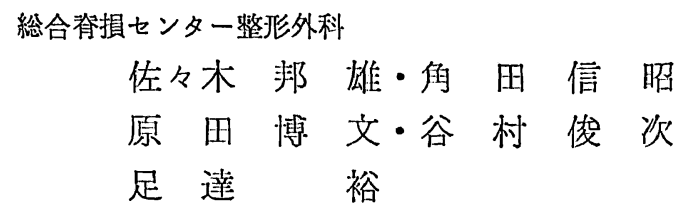

別付整肢園整形外科

佐 竹 孝 之・岩田信彦
後 藤 元 德

Thermographic study in idiopathic scoliosis

by

K. Sasaki, N. Tsunoda, H. Harada, S. Tanimura Y. Adachi

Orthopaedic Surgery, Spinal Injuries Center, Iizuka.

T. Satake, N. Iwata and M. Goto

Orthopaedic surgery, Crippled Children Hospital, Beppu.

\begin{abstract}
Although etiology of idiopathic scoliosis is unknown, we designed to investigate thermography of back in idiopathic scoliosis and discuss its usefulness. Thermographic examination was performed in 142 children. 19 children had straight spines, 24 had functional curves and 99 sustained idiopathic scoliosis. We compared their thermographies and X-ray films of them. We showed criteria of the thermography. We suggested that in screening of spinal deformity thermographic observation was useful and it gave us functional factor in scoliosis.
\end{abstract}

緒 言

特発性側彎症の原因・予後予測について見時点では 明確なものはない，側誉症の治療は Milwaukee brace を代表とする矯正装具, Harrington instrumentation system 等の手術的治療の進歩汇より積 極的に行われている.しかし，治療の重要な面として 予防医学の観点をも含めた早期発見へのアプローチも 本疾患の性質上大切な事柄である．我が国においては 昭和 54 年より 学童の定期健康診断の際, 脊柱変形の 有無をチュックすることが義務づけられた．早期発見 の手段として現在まで, 視診, 背部隆起測定法, モア レ法が用いられている. 我々は第 15 回側揧症研究会 において，棈築学的側梨症における背部皮沜渦は何等 かの形で非対称性を示すととを報告した. 本方法は児
童に対する障管もなく，又，此校的多くの人数に刘し てむ使用できるので侧縞症のスクリーニングの手段と して利用できるのではと考えた. 又, 本法が北部の血 流を反咉していることより侧彎症における福態を示唆 している可能性む考えられた。

今回，同時に报影したX線学的検討に基づき沴断し た正常 19 例, 機能性倒彎 24 例, 槛筑性倒彎 99 例飞 おける背部皮滒温（以下サーモ之略す）を测定し，そ の分布北態を先に述べた钼点（スクリーニングとして

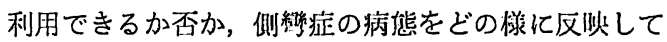
いるか) より検討したので報告する.

1. 目的

特発性側称症の治療においては早期発見が更要であ り, non-invasive なサーモが変形の発见に有用か否 加を求めた。 
特発性倒卛症の原因についてはいまだ明確なものは ないが，本法が主として撮影部位の血流を反映してい るととより，サーモの分们形態により変形㝓柱:の如何 なる情報，眼ち，回侧或は叫侧に血流が多いのか，力 ーブパターンにより差置があるのか，本方法はカーブ

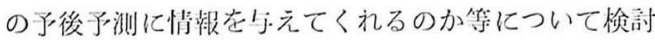
した.

\section{2. 方 法}

サーモは客温約 $25^{\circ}$ に衣服得脱後 5 分, 來位, 再 上肢下垂位にて据影した，座位にて行ったのは，骨盤 を固定させることにより回旋によるサーモの変化を避 ける為である。 今回使用したサーモグラフィー装置は 日本西子の JTG-MD であり，温度幅は５段階に設定 した(図 1 ).

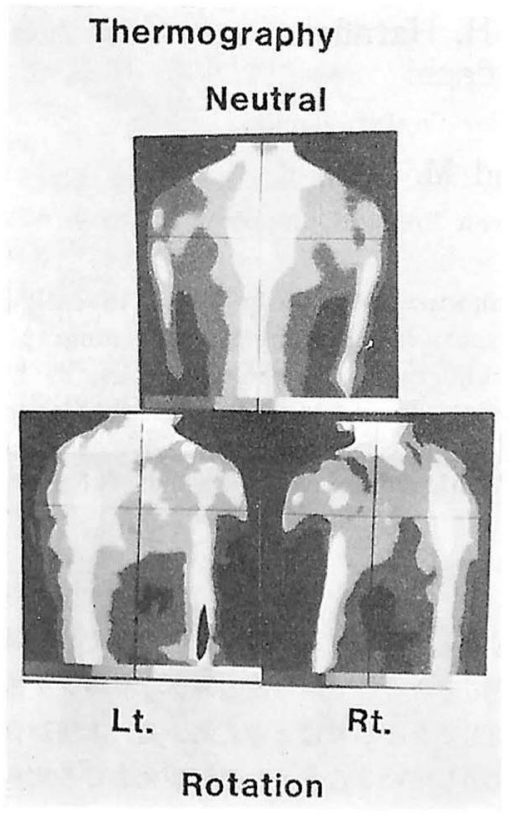

図1回旋によるリーモ像の变化

\section{3. 対 象}

今回サーモとレ緗の比洨を行った症例は，当科を食 柱変形を主訴として受部した患者及び，学校健彰によ りチェックされ別府整肢图を受獄した 142 例である （受衫例のうち 手術走要する症例 は今回対象外とし た).

立位亚びに邟位レ總像で判定した金症例の内訳は， 正常 19 例, 機能性倒彎 24 例, 特発性側蕃症 99 例 で あった．男性は 44 例，女性は 98 例であった。機能性
側彎の内左凸カーブは 17 例であり，構築性カーブに おいては右凸カーブが 40 例之最も多かった。 シング ルカーブが 67 例ありロ側が右側の屯のが 49 例であっ た. ダブルカーブは 29 例あり, 大部分が右凸胸椎左 凸胸腰椎・腰椎タイプであった（表 1 ）。

表1 楛築性カーブを有した症例のクイプ分類 TYPE of CURVES (structural)

\begin{tabular}{|c|c|c|c|}
\hline TYPE & CASES & AGE yrs & ANGLE degree \\
\hline \multicolumn{4}{|l|}{ Single } \\
\hline $\mathrm{rt} \mathrm{T}$ & 40 & 14.3 & $17.5 \pm 8.8$ \\
\hline rt TL, I & 9 & 13.5 & 13. $4 \pm 3.7$ \\
\hline lt $T$ & 5 & 13.6 & $11.0 \pm 3.7$ \\
\hline it TL, L & 13 & 13.5 & 13. $4 \pm 3.7$ \\
\hline \multicolumn{4}{|l|}{ Double } \\
\hline $\mathrm{rt} \mathrm{T}$ & 22 & 142 & $24.8 \pm 9.3$ \\
\hline lt $\mathrm{TL}, \mathrm{L}$ & 22 & 14.4 & $21.7 \pm 5.6$ \\
\hline It UT & & & $21.7 \pm 5.1$ \\
\hline $\begin{array}{l}+ \\
\text { rt }\end{array}$ & 7 & 14.6 & $19.6 \pm 6.0$ \\
\hline
\end{tabular}

T: thoracic TL: thoracolumbar

L: lumbar UT: upper thoracic

\section{4. サ一モの判定方法}

判定の方法及び基準は，サーモ像において頸部より 正中線を引きてれ基準線として左右の非刘称性をみ た. 判定は視覚にて行うので判定者の主钼の入る余地 があり，乙れは判定方法の欠点であろう.

A. 先づ全体的にみて対称的加否かを決定し刘称的 なグループを抽出する.

B． 非刘称的なグループにおいて

非刘称的なグループにおいては高温域の左右差を決 めるわけであるが，以下に述べる方法により 決定し た.

a. 正中付近での明らかな左右差.

b. 外側部での明らかな左右差.

c. 一側への高温域の島状域は斑点状の拡大.

以上の 3 法でも高温域の判定でしがたいもの，又， 正中と外侧で高温域の異なるものはサーモ買常で判定 不能とした.

前記高温域の判定基準にて高温域を決定し右高温或 いは左高温とした.

(1) 侧彎症においては胸椎部カーブが多くを占める ととより, 先づ胸椎部において高温域を決定した.

(2) 胸椎部において刘称的な場合は，屃及び腰部の 刘称性の有無を検討し高温域を決定した。 


\section{5. 結 果 (表 2)}

サーモグラフィーを先述の如き判定基準にて分類す ると対称的 17 例, 右高温 58 例, 左高温 57 例, 暴常 10 例であった.

表 2 カーブ方向とサーモ像の比較検討 (我々の判定基準による)

\begin{tabular}{l|c|c|c|c|c}
\hline \hline & 対 称 & 右高温 & 左高温 & 異常 & 計 \\
\hline 右 凸 & $2(0)$ & $28(5)$ & $15(1)$ & $4(0)$ & $49(6)$ \\
左吕 & $3(5)$ & $5(3)$ & $9(9)$ & $1(1)$ & $18(18)$ \\
Double & 0 & 14 & 14 & 1 & 29 \\
正 常 & 7 & 2 & 9 & 1 & 19 \\
\hline & $12(5)$ & $49(8)$ & $47(10)$ & $7(1)$ & $115(24)$
\end{tabular}

\section{（）内は機能性侧矮症例を示す}

肥沙による皮下脂肪の差がサーモ像において差基を 示すか否かを Rohrer 指数を用いて検討すると，異 常群が平均值にて高い傾向を示すむバラッキがあり各 群間における統計的有意差は認められなかった。

サーモ像とレ線の比較において次の様な結果を得 た.

先づレ線にて判定した 正常 及び 異常（機能性む含 む)において統計学的に検討すると, 異常例は正常例 に比し 明らかに非対称サーモ像を示していた（ $\mathrm{P}<$ 0.05).

正常例においては 19 例中 7 例が 対称的であり，非 対称的なむの 12 例中 9 例は左高温を示していた.

カーブ方向とサーモ高温城の一致についてみると, 右凸カーブで右高温を示すすのは棈築性 49 例 中 28 例，機能性 6 例中 5 例であった. 又，左凸カーブで左 高温を示すむのは棈築性で 18 例中 9 例，機能性で 18 例中 9 例に一致をみた. カーブ凸側と高温域の一致を 統計学的に検討すると棈筑性シングルカーブのみでは 一致を示さないむ，機能性カーブを含めると $\mathrm{P}<0.05$ で高温域とカーブ凸側が一致する傾向を示した。これ は機能性カーブにおける一致率が高いことを示してい た.

\section{6. 考 察}

特発性側彎症の原因は末だ不明である，従来より， 体幹及び脊椎の筋肉の不均衡, 中枢性の姿勢制御の異 常, 椎体の成長障害, 内分泌系の異常等がかえられ, 種々の実験的並びに臨床的研究がなされている.

我々は側警症の原因は不明であるが後方の肋横勒崇 を介しての支持機構の破綻は何等かの形で発症及び進
行に関与していると考えている. 実験的に, ラット使

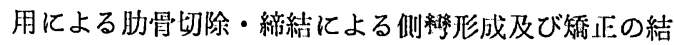
果を発表してきだ)4. Х，臨休酒においても，Mehta の方法に準じて顶椎部を中心として肋骨・棑体角を测 定することにより，後方部の要䒺にあ注目する必要の あるととを述べた5). サーモは皮成表面における赤外 線の放散を感知するむのであり，主としてその部の血 流を反映する．とのことは侧橉病:においてサーモを测

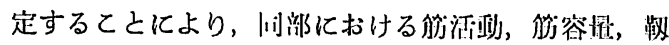

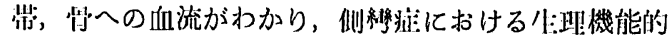
な面む反映すると考えられる。

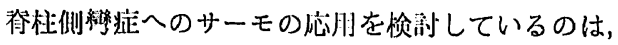
睍在まで著者の则る限りでは, Cooke ${ }^{1)}$, Sibilla ${ }^{6}$, 川 上2)がある，彼等によるデータは判定及び絬果におい

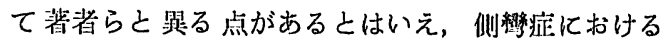
サーモは異常像を示すという点においては一政してい

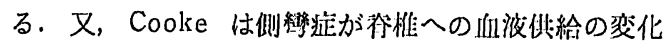
を伴っていると述べ1)，Sibilla は digital computer

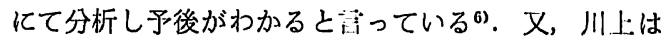

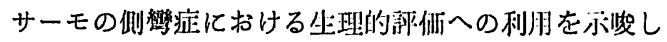
ている2).

脊柱変形の早期発見の方法としての伐用は, 我々の 結果より充分可能亡考えら机る. 监及しつつむるモア レ法と同様な非態学的変化をとらえる面む幾分あると は言え，機能的な面をかなり令んでいるのでより利用

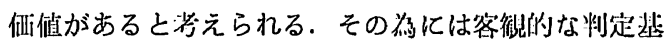
準が望ましい，我々の春柱暴常例に括けるサーモ刘称

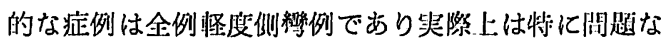
いと考えられた. 又，明きらかなカーブは全例サーモ 非刘称を示し，治療を要する例が楁ちこぼれる伦偷性 あ少ないと考えられた。

生理機能的な面での有用性の有低について検尌する 為には，判定方法，报影壯の工头等更なる改良が必要 と考えられた。我々は少述の判定基準により凸侧が高 温を示す倾向であると言う結果を得たが，乙の判定絬 果は実際の症例において凸侧が高温を示すむののみで なく，ある症例においては脊椎の侧方㤝位の為凹侧が 凹側に位置し凹侧に高温域が存仼してあ凸侧高温と判 定される可能性は充分ある.乙の樨な不明峰な事を防 ぐには，欶笑起にマークをして，それにより左右差を みる必要があろう.しかし，スクリーニングの際は煩 熦であり，サーモを我々のう法で判定するのみで允分 とあ考えられる. 又, 詳細な分析には, Sibilla が述 
ベている如く digital computer の使用む有用であろ $j^{6)}$.

\section{結語}

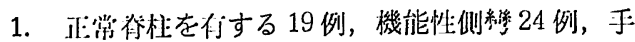
術を装しない特発性侧釉症 99 例において北部皮们温 を测定し，レ線像と刘比検詥した。

2. カーブの判定は全例レ線像にて行った. 又, 背 部皮得温は空温約 $25^{\circ}$ にて测定した。

3. 北部皮游温の判定方法について述べた.

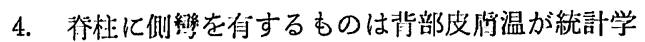
的有意差をむって非対称像を示した。

5. 背部皮得温の雷温域とカーブの山側は一致する 倾向を示すむ, 判定法に問題があることを述べた.

6. 背部皮笉温测定は脊柱変形のスクリーニングの 方法として充分利用出来, 又, 生理機能的な面からの 分析む可能なととを述べた.

\section{文献}

1) Cooke, E. D. et al.: Identifying scoliosis in adolescent with theormography. A preliminary study. Clin. Orthop., 148: 172-176, 1980.

2）川上俊文・他：侧警症患者の北部皮䄈温の微 察. 整形外科と災皆外科, $30: 228-230,1981$.

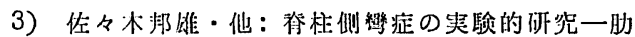

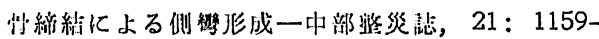
1161, 1978.

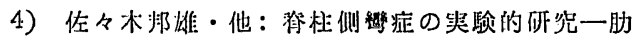
修䋨絬による侧溉形成及び矮正について一，中部
整災誌，23:664-666, 1980.

5）佐々木邦推・他：胸椎部側释における助骨の意 義一助骨椎体角儿上る検討一整形外科と災害外 科, 30, 238-242, 1981 .

6) Sibilla, P.: Possibilities of a prognostication of small scoliosis. SICOT, 1981, in Brasil.

質 問山陰労災 那須 吉郎 左右の非対称をきたす原因をどのようにお考えでし ょうか?

回答総合脊損センター 佐々木邦雄 背部皮等温に異常がみられるということは，筋血流 量をむ反映した意味で，カーブの性質を何等らの形で 示していると思われ，今後予測をむ含め検討したい.

質 問 宮崎医科大学整形外科 武内 晴明

1. サーモグラフィーでの皮フ温の左右差は筋の 活動性を示しているのか，それとすミラーと被写体間 の距離の差を現わしているのか.

2. サーモによる皮フ温左右差の程度と実際の Cobb 角之の間にはかなりの相関関係がみら゙れるか, 又スクリーニングとして使用可能であるか.

回 答総合脊損センター 佐々木邦雄 背部隆起と皮原温の検討は症例が少なかったので行 っていません.

$\mathrm{Cobb}$ 角とサーモの比較検討は行っていません. 